\title{
ESTIMATING EMISSIONS OF HARMFUL EXHAUST COMPONENTS BY AIRCRAFT ENGINES DURING THE TAKEOFF AND LANDING CYCLE IN AIRPORT SPACE
}

\author{
Paweł Głowacki* (iD 0000-0001-9852-095X \\ Piotr Kalina (DD 0000-0003-3326-7476 \\ Michal Kawalec (D) 0000-0003-3147-3516 \\ Łukasiewicz Research Network - Institute of Aviation, Al. Krakowska 110/114, 02-256 Warsaw \\ *pawel.glowacki@ilot.lukasiewicz.gov.pl
}

\begin{abstract}
This article examines, based on the available information and authors' self-assessments, the environmental impact of turbine engine exhaust gases effect on the environment in the airport space during engines flight phases in the landing and takeoff cycle (LTO). The attention of aviation professionals is drawn to the fact that the amount of exhaust from the turbine engine is so significant that it may adversely change the ambient air at the airport. Consequently, increased emission level of carbon monoxide (CO), hydrocarbons (HC) during engine start-up and idle may pose a threat to the health of ramp staff. Also, high emission levels of nitrogen oxides $\left(\mathrm{NO}_{\mathrm{x}}\right)$ during takeoff, climb, cruise and descent is not without importance for the environment around the airport space. The paper gives $\mathrm{CO}_{2}, \mathrm{HC}, \mathrm{CO}$ and $\mathrm{NO}_{\mathrm{x}}$ emission estimations based on ICAO Engine Emission Data Bank and the number of passenger operations at a medium-sized airport. It also provides calculation results of aircraft $\mathrm{CO}_{2}, \mathrm{HC}, \mathrm{CO}$ and $\mathrm{NO}_{\mathrm{x}}$ emission using average times of aircraft maneuvers taken from aircraft Flight Data Recorder (FDR) in the LTO cycle various aircraft types at the airport. The latter, based on actual maneuvering times, lead to significantly reduced estimates of toxic exhaust gas emission volumes.
\end{abstract}

Keywords: Ecology, aircraft turbine engine, engine exhaust, toxic exhaust gas components, nitrogen oxides, carbon monoxide, hydrocarbons, carbon dioxide

Type of the work: Case Study

\section{INTRODUCTION}

Currently, large and very large thrust (from $100 \mathrm{kN}$ to more than $500 \mathrm{kN}$ ) twin flow fan turbine jet engines are used for aircraft propulsion. They cause more than $2000 \mathrm{~kg}$ of $\mathrm{CO}_{2}$ to be emitted during the first three minutes of takeoff and climb of a widebody aircraft. It should be stressed, however, that aviation currently emits only around 3\% of all greenhouse gas emissions produced by humanity. However, the toxic compounds are in this case concentrated in a limited area. In order to assess the scale of toxic compound processes and their dispersion in the limited airport area, a medium-sized airport was selected for study. At present, depending on the season, about 500-600 passenger operations are performed there, accumulated mainly in the morning and afternoon hours. at several minute intervals. Hot exhaust gases 
from turbine engines are a mixture of residual air $\left(\mathrm{N}_{2}\right.$ and $\left.\mathrm{O}_{2}\right)$, and combustion products (mainly $\mathrm{CO}_{2}$ and $\mathrm{H}_{2} \mathrm{O}$ ) and the resulting toxic components. The low density of the exhaust gases causes them to rise upwards in the cool air environment (compared to the temperature of these exhaust gases, which reaches several hundred degrees Celsius). The directed stream of exhaust gases mixes with the surrounding air, gradually "blurring" inti the atmosphere. $99.3 \%-99.5 \%$ of jet engine exhaust gases is comprised of $\mathrm{N}_{2}$, $\mathrm{O}_{2}, \mathrm{CO}_{2}$ and $\mathrm{H}_{2} \mathrm{O}$. The remaining $0.7 \%-0.5 \%$ contains $\mathrm{NO}_{\mathrm{x}}, \mathrm{CO}, \mathrm{HC}$, including soot. The standards in aviation currently in force concern precisely the latter compounds, and they are included in the ICAO's Annex 16 Environmental Protection, Volume 2, Emissions of Aviation Engines [6].

\section{MEASUREMENT OF EXHAUST GASES EMISSIONS}

The amount of emitted harmful compounds, measured for the so-called takeoff and landing (LTO) cycle, is graphically depicted in Fig. 1.

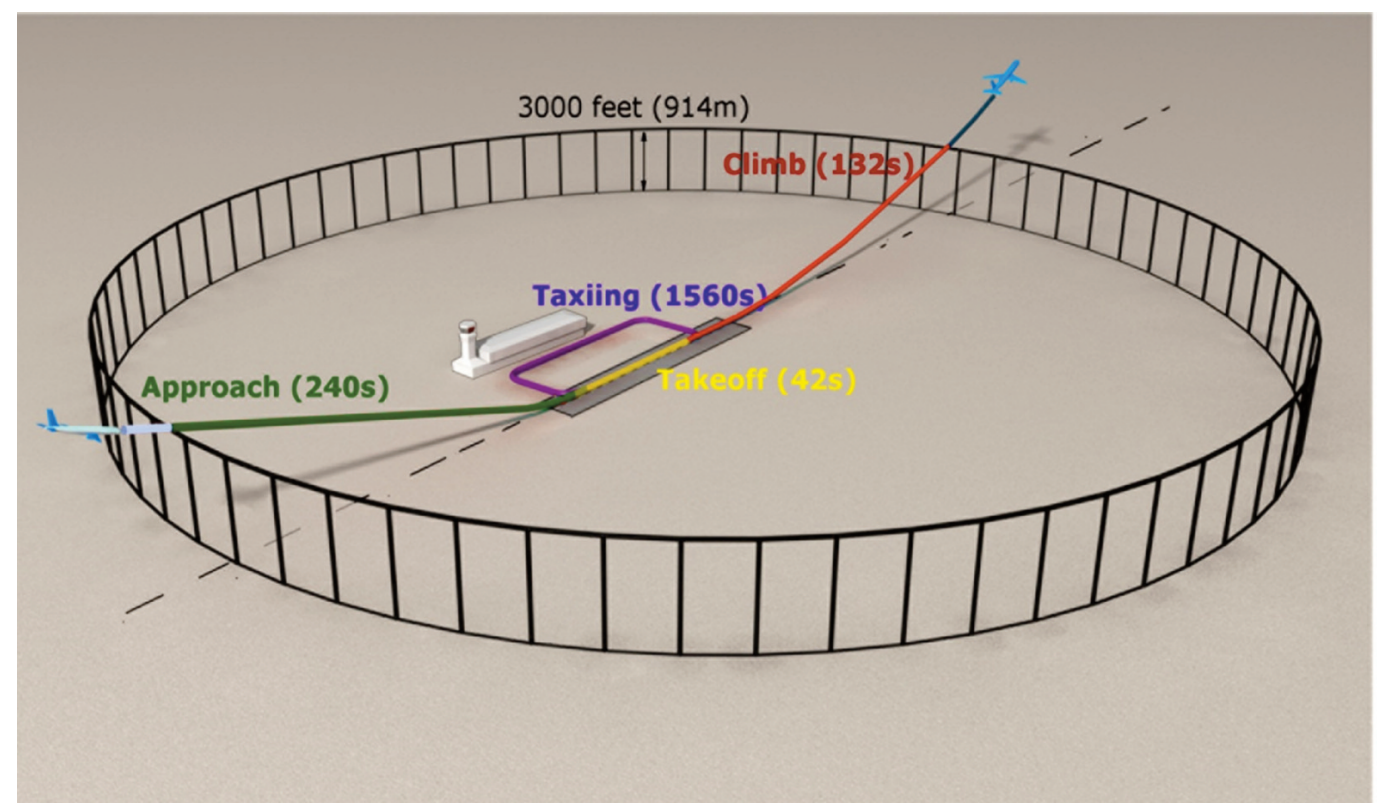

Fig. 1. Graphical presentation of the LTO cycle as defined by ICAO.

Parameters defining this cycle vary and take on magnitudes depending on whether the engines are intended to power subsonic or supersonic aircraft. Additionally, for subsonic aircraft engines, $\mathrm{NO}_{\mathrm{x}}$ emission is calculated differently depending on date of their manufacture, starting thrust and compression, and only for those with thrust above $26.7 \mathrm{kN}$. Details can be found in [6]. Unlike noise tests, precise measurements cannot be made during engine operation. They are performed only by the manufacturer at the engine test cell according to the procedures described in Annex 16, Volume 2 [6]. Test results are recorded on a special form available in the ICAO Engine Exhaust Emissions Data Bank [7], and engines must meet the required standards. Tables 1 and 2 present a description of the LTO cycle "definition" according to the ICAO, showing at what ranges and operating conditions of the jet engine the quantitative values of emissions of the above-mentioned harmful substances are determined for: (a) subsonic airplanes, (b) supersonic airplanes. 
Table 1. (a) Thrust settings and time duration of subsonic aircraft flight phases.

\begin{tabular}{|l|c|c|}
\hline $\begin{array}{l}\text { Flight Range } \\
\text { (Phase) }\end{array}$ & $\begin{array}{l}\text { Engine } \\
\text { thrust in [\%] } \\
\text { KSTART. }\end{array}$ & $\begin{array}{l}\text { Duration } \\
\text { [min] }\end{array}$ \\
\hline TAKEOFF & 100 & 0.7 \\
\hline CLIMB & 85 & 2.2 \\
\hline APPROACH & 30 & 4.0 \\
\hline TAXIING & 7 & 26.0 \\
\hline
\end{tabular}

Table 2. (b) Thrust settings and time duration of supersonic aircraft flight phases.

\begin{tabular}{|l|c|c|}
\hline $\begin{array}{l}\text { Flight Range } \\
\text { (Phase) }\end{array}$ & $\begin{array}{l}\text { Engine } \\
\text { thrust in [\%] } \\
\text { KSTART. }\end{array}$ & $\begin{array}{l}\text { Duration } \\
\text { [min] }\end{array}$ \\
\hline TAKEOFF & 100 & 1.2 \\
\hline CLIMB & 65 & 2.0 \\
\hline DESCENT & 15 & 1.2 \\
\hline APPROACH & 34 & 2.3 \\
\hline TAXIING & 5.8 & 26.0 \\
\hline
\end{tabular}

\section{EMISSIONS OF SPECIFIC COMPONENTS OF EXHAUST GASES FROM AIRCRAFT ENGINES AT A MEDIUM-SIZED AIRPORT OVER THE LTO CYCLE}

Table 3. Types and number of engines during daily operations.

\begin{tabular}{|l|c|}
\hline Engine type & Average/day \\
\hline CF34-10E5 & 23 \\
\hline CF34-10E7 & 77 \\
\hline CF34-8C1 & 6 \\
\hline CF34-8C5 & 31 \\
\hline CF34-8E & 52 \\
\hline CF34-8E5 & 33 \\
\hline CF6-80C2B2F & 1 \\
\hline CF6-80C2B6F & 3 \\
\hline GE90-115B & 2 \\
\hline GEnx-1B & 4 \\
\hline CFM56-5B6/P & 1 \\
\hline CFM56-3C1 & 4 \\
\hline CFM56-5B1/3 & 1 \\
\hline CFM56-5B2/P & 1 \\
\hline CFM56-5B3/P & 12 \\
\hline CFM56-5B4/P & 1 \\
\hline CFM56-5B4-2 & 10 \\
\hline CFM56-5B5/3 & 1 \\
\hline CFM56-5B5/P & 1 \\
\hline CFM56-5B6/3 & 1 \\
\hline CFM56-5B6/P & 1 \\
\hline CFM56-5C4/P & 1 \\
\hline CFM56-7B & 1 \\
\hline CFM56-7B22 & 1 \\
\hline CFM56-7B24 & 1 \\
\hline CFM56-7B26 & 1 \\
\hline CFM56-7B27 & 1 \\
\hline CFM56-7BE & 1 \\
\hline
\end{tabular}

\begin{tabular}{|l|c|}
\hline Engine type & Average/day \\
\hline CFMI LEAP-1A & 1 \\
\hline CFMI LEAP-1A26 & 1 \\
\hline CFMI LEAP-1A32 & 1 \\
\hline IAE V2522-A5 & 10 \\
\hline IAE V2527-A5 & 1 \\
\hline IAE V2530-A5 & 34 \\
\hline IAE V2533-A5 & 3 \\
\hline PW-1127G & 1 \\
\hline PW1133G & 2 \\
\hline PW124B & 2 \\
\hline PW127F & 1 \\
\hline PW1500G & 85 \\
\hline PW150A & 1 \\
\hline PW1524G & 1 \\
\hline PW306D & 1 \\
\hline PW307D & 1 \\
\hline PW545C & 1 \\
\hline R-R Pearl & 1 \\
\hline RR Trent XWB & 7 \\
\hline Trent 1000 & 5 \\
\hline Trent 1000 320 kN & 1 \\
\hline Trent 772B-60 & \\
\hline RB211-535 & 1 \\
\hline Tay 611-8C & 1 \\
\hline & \\
\hline & 1 \\
\hline & 1 \\
\hline & 1 \\
\hline
\end{tabular}


Based on the data provided from the Airport Authorities, the average number of engines per day emitting exhaust gases during the LTO cycle in winter was determined. Their number and type are presented in Table 3.

On the basis of the data contained in the ICAO engine emissions database [7], for each engine type its emissions were calculated over the LTO cycle according to the ICAO definition, taking into account the daily number of flight operations for that engine. Example engine emission calculations are given in Tables 4 and 5.

Table 4. TRENT 772 thrust $320.3 \mathrm{kN}$.

\begin{tabular}{|c|c|c|c|c|}
\hline & $\begin{array}{c}\text { Actual } \\
\text { emission } \\
\mathrm{CO}_{2}\end{array}$ & $\begin{array}{c}\text { Actual } \\
\text { emission } \\
\mathrm{NO}_{x}\end{array}$ & $\begin{array}{c}\text { Actual } \\
\text { emission } \\
\mathrm{CO}\end{array}$ & $\begin{array}{c}\text { Actual } \\
\text { emission } \\
\mathrm{HC}\end{array}$ \\
\hline $\begin{array}{c}\text { Engine data from } \\
{[\mathrm{kg}]}\end{array}$ & 3369 & 17.668 & 10.606 & 1.048 \\
$\begin{array}{c}\text { ICAO engine emissions } \\
\text { data bank }\end{array}$ & 3369 & 17.668 & 10.606 & 1.048 \\
\hline $\begin{array}{c}\text { Considering amount of } \\
\text { engines per day }\end{array}$ & 3369 \\
\hline
\end{tabular}

Table 5. CF34-10E7 thrust $83.7 \mathrm{kN}$.

$\left.\begin{array}{|c|c|c|c|c|}\hline & \begin{array}{c}\text { Actual } \\ \text { emission } \\ \mathrm{CO}_{2}\end{array} & \begin{array}{c}\text { Actual } \\ \text { emission } \\ \mathrm{NO}_{\mathrm{x}}\end{array} & \begin{array}{c}\text { Actual } \\ \text { emission } \\ \mathrm{CO}\end{array} & \begin{array}{c}\text { Actual } \\ \text { emission } \\ \mathrm{HC}\end{array} \\ \hline \begin{array}{c}\text { Engine data from } \\ \text { ICAO engine emissions } \\ \text { data bank }\end{array} & 1018 & 3.341 & 6.430 & 0.601 \\ \hline \begin{array}{c}\text { Considering amount of } \\ \text { engines per day }\end{array} & 78386 & 257 & 4 \mathrm{~kg}]\end{array}\right]$

If it is assumed that aircraft maneuvers take as much time as described in the definition of the LTO cycle in the ICAO document [6], then: the daily $\mathrm{CO}_{2}$ emissions from aircraft - excluding state aviation, which has a negligible impact - would be: $538028 \mathrm{~kg}$. In a conventional winter period, the volume of $\mathrm{CO}_{2}$ emissions at the medium-sized airport would be $538028 \times 182=$ about 97921 tons. Each day the emissions of hydrocarbons (HC) would be $159.882 \mathrm{~kg}$, carbon monoxide (CO) $2009.152 \mathrm{~kg}$, and nitrogen oxides $\left(\mathrm{NO}_{\mathrm{x}}\right) 2016.037 \mathrm{~kg}$. During the winter period, these emissions would be about 29.1 tons for HC, about 366 tons for $\mathrm{CO}$ and about 367 tons for $\mathrm{NO}_{\mathrm{x}}$.

These figures are accurate only for 490 passenger operations per day, i.e. 245 takeoffs and the same number of landings. Based on the data published by the Civil Aviation Authority "Number of passengers served and operations performed in domestic and international traffic - regular and charter", it may be assumed that in summer, the daily number of passenger operations is about $24 \%$ higher than in winter. Thus, the emissions of the engine exhaust gas components discussed in the study would be: about 121422 tons for $\mathrm{CO}_{2}$, about 36 tons for $\mathrm{HC}$, about 453 tons for $\mathrm{CO}$ and about 455 tons for $\mathrm{NO}_{\mathrm{x}}$. 


\section{EMISSIONS OF SELECTED COMPONENTS OF EXHAUST GASES FROM AIRCRAFT ENGINES AT MEDIUM-SIZED AIRPORT OVER THE LTO CYCLE TAKING INTO ACCOUNT THE AVERAGE DURATION OF AIRCRAFT MANEUVERS}

Operational practice in aviation is, nonetheless, more complex than this simplification of assuming constant parameter values as in the ICAO LTO cycle determination methodology. After installation on the airframe, engines do not behave as they did on the test station and their parameters differ from those measured under almost laboratory conditions. Different engines operated by operators, even of the same type and version, have in fact different characteristics. Moreover, in the process of use and maintenance there is a gradual deterioration of the characteristics and the amount of fuel needed to provide the same thrust value increases significantly in comparison to the amount needed after installation of a new engine on the airframe. Also, the so-called EGT margin decreases, which means that the temperature of the exhaust gases on the takeoff range may approach the limit not to be exceeded. During takeoff, depending on the aircraft weight, runway length and external conditions, pilots apply thrust derate or thrust reduction. It is sometimes the case that an aircraft performs the takeoff maneuver with the engine thrust 20\% lower than its maximum takeoff thrust value, which significantly reduces $\mathrm{NO}_{\mathrm{x}}$ emissions. Depending on the decisions of the air traffic control, the profiles and thus the duration of climb and approach maneuvers sometimes vary. In addition, the specificity of each airport results in highly variable taxi times, including stops to wait in line for both taxiing and takeoff. Therefore, to more realistically estimate the amount of emitted harmful compounds of jet engine exhaust at medium-sized airport, averaged aircraft maneuvering times were assumed. They were calculated on the basis of the maneuver times recorded on the flight data recorders of six aircraft types. The results are presented in Table 6 below.

Table 6. Duration of aircraft maneuvers based on data from flight data recorders compared to ICAO.

\begin{tabular}{|l|l|l|l|l|}
\hline Maneuver & $\begin{array}{l}\text { Average duration } \\
\text { of maneuvers } \\
\text { calculated from } \\
\text { flight data } \\
\text { recorders }\end{array}$ & $\begin{array}{l}\text { Average duration } \\
\text { of maneuvers } \\
\text { calculated from } \\
\text { flight data } \\
\text { recorders }\end{array}$ & $\begin{array}{l}\text { Duration } \\
\text { of ICAO } \\
\text { LTO } \\
\text { maneuvers }\end{array}$ & $\begin{array}{l}\text { Correlatio } \\
\text { n } \\
\text { Coefficient }\end{array}$ \\
\hline TAKEOFF & 43 & 0.72 & 0.7 & 1.01 \\
\hline CLIMB & 76 & 1.27 & 2.2 & 0.57 \\
\hline APPROACH & 267 & 4.45 & 4 & 1.11 \\
\hline TAXIING & 1149 & 19.15 & 26 & 0.74 \\
\hline
\end{tabular}

Note the significantly shorter duration of the climb and taxi maneuvers, and only slightly longer takeoff and approach maneuvers compared to those defined by ICAO for the LTO cycle. Emission values of particular components of engine exhaust gases (defined as "Actual") given in the following tables take into account the average time of maneuvers of particular flight phases of aircraft calculated on the basis of data recorded on their on-board recorders. Examples of specific engine emissions calculations considering actual time of maneuvers are given in Tables 7 and 8. These are the same engines shown in Tables 4 and 5, making it possible to compare the influence of the actual and ICAO-defined maneuvering time on engine exhaust emission. 
Table 7. TRENT 772 thrust $320.3 \mathrm{kN}$.

\begin{tabular}{|l|c|c|c|c|}
\hline Maneuver & $\begin{array}{c}\text { Actual } \\
\text { emission } \mathbf{C O}_{2}\end{array}$ & $\begin{array}{c}\text { Actual } \\
\text { emission } \text { NO }_{\mathbf{x}}\end{array}$ & $\begin{array}{c}\text { Actual } \\
\text { emission CO }\end{array}$ & $\begin{array}{c}\text { Actual emission } \\
\text { HC }\end{array}$ \\
\hline Takeoff & {$[\mathbf{k g}]$} & {$[\mathbf{k g}]$} & {$[\mathbf{k g}]$} & {$[\mathbf{k g}]$} \\
\hline Climb & 415 & 4.754 & 0.028 & 0.001 \\
\hline Approach & 596 & 5.149 & 0.094 & 0.002 \\
\hline Taxiing & 680 & 2.282 & 0.342 & 0.009 \\
\hline Total emissions & 962 & 1.444 & 7.431 & 0.763 \\
\hline $\begin{array}{l}\text { Considering amount } \\
\text { of engines per day }\end{array}$ & $\mathbf{2 6 5 3}$ & $\mathbf{1 3 . 6 2 5}$ & $\mathbf{8 . 1 2 5}$ & $\mathbf{0 . 7 7 5}$ \\
\hline
\end{tabular}

Table 8. CF34 - 10E7 thrust $83.7 \mathrm{kN}$.

\begin{tabular}{|l|c|c|c|c|}
\hline Maneuver & $\begin{array}{c}\text { Actual } \\
\text { emission } \mathbf{C O}_{2}\end{array}$ & $\begin{array}{c}\text { Actual } \\
\text { emission } \text { NO }_{\mathbf{x}}\end{array}$ & $\begin{array}{c}\text { Actual } \\
\text { emission CO }\end{array}$ & $\begin{array}{c}\text { Actual emission } \\
\text { HC }\end{array}$ \\
\hline Takeoff & {$[\mathbf{k g}]$} & {$[\mathbf{k g}]$} & {$[\mathbf{k g}]$} & {$[\mathbf{k g}]$} \\
\hline Climb & 115 & 0.759 & 0.019 & 0.0004 \\
\hline Approach & 170 & 0.923 & 0.021 & 0.0027 \\
\hline Taxiing & 202 & 0.530 & 0.219 & 0.0039 \\
\hline Total emissions & 314 & 0.376 & 4.542 & 0.4350 \\
\hline $\begin{array}{l}\text { Considering amount } \\
\text { of engines per day }\end{array}$ & $\mathbf{8 0 1}$ & $\mathbf{2 . 5 9}$ & $\mathbf{4 . 8}$ & $\mathbf{0 . 4 4 2}$ \\
\hline
\end{tabular}

Considering the aircraft maneuvering times averaged from the data on their flight recorders, it was calculated that daily $\mathrm{CO}_{2}$ emissions from aircraft - excluding state aviation, which has a negligible impact - are $379613 \mathrm{~kg}$. In the conventional winter period, the volume of $\mathrm{CO}_{2}$ emissions at the medium-sized airport is $379613 \times 182$ = about 69090 tons. Each day the emissions of hydrocarbons (HC) are 119.478 $\mathrm{kg}$, carbon monoxide (CO) $1539.593 \mathrm{~kg}$, and nitrogen oxides $\left(\mathrm{NO}_{\mathrm{x}}\right) 1573.444 \mathrm{~kg}$. In the winter period, these emissions were about 22 tons for $\mathrm{HC}$, about 280 tons for $\mathrm{CO}$ and about 286 tons for $\mathrm{NO}_{\mathrm{x}}$. It should be emphasized that these values are much smaller than those calculated on based of the current LTO cycle definition - the relative reductions in the estimated emissions of particular harmful compounds were as follows: by $29.5 \%$ for $\mathrm{CO}_{2}$, by $25 \%$ for $\mathrm{HC}$, by $23 \%$ for $\mathrm{CO}$ and by $22 \%$ for $\mathrm{NO}_{\mathrm{x}}$. On the basis of data published by the Civil Aviation Office it was assumed that during the summer period, the daily number of passenger operations is higher by about $24 \%$. In view of this, the emissions analyzed in the study are estimated at: about 85672 tons for $\mathrm{CO}_{2}$, about 27 tons for $\mathrm{HC}$, about 347 tons for $\mathrm{CO}$ and about 355 tons for $\mathrm{NO}_{\mathrm{x}}$. 


\section{SUMMARY AND CONCLUSIONS}

For the conditions adopted in the paper, that is, the number of aircraft operations in contractual periods of the year, the manner in which aircraft maneuvering times were calculated, and the determination of the number and types of engines operating daily at the airport, the annual emissions at the mediumsized airport studied are presented in Table 9. It also includes the emissions for the takeoff and landing cycle as defined by ICAO.

Table 9. Annual emissions at the airport.

\begin{tabular}{|c|c|c|c|c|}
\hline LTO cycle & $\begin{array}{l}\text { Emission of } \\
\mathrm{CO}_{2} \\
\quad[\mathrm{t}]\end{array}$ & $\begin{array}{l}\text { Emission of } \\
\mathrm{NO}_{\mathbf{x}} \\
\quad[t]\end{array}$ & $\begin{array}{l}\text { Emission of } \\
\mathrm{CO} \\
\quad[\mathrm{t}]\end{array}$ & $\begin{array}{l}\text { Emission of } \\
\text { HC } \\
\qquad[t]\end{array}$ \\
\hline ICAO & 219343 & 822 & 819 & 65 \\
\hline $\begin{array}{l}\text { Including actual } \\
\text { aircraft maneuvering } \\
\text { times }\end{array}$ & 154762 & 641 & 628 & 49 \\
\hline
\end{tabular}

Significantly smaller emissions from aircraft in airport space become obvious when only the average duration of maneuvers is taken into account in the estimation. Accurate knowledge of the actual amount of emissions is important, especially for airport managers, to help estimate the environmental impact of airport operations. It is also necessary to determine their dispersion and concentration locations. In further calculations of the amount of emitted toxic components of exhaust gases emissions, the actual fuel consumption of the engines during the various phases of the LTO cycle should be taken into account on the basis of flight recorder data.

\section{Aknovledgements}

This paper has been based on the results of a research task carried out within the scope of the fifth stage of the National Programme "Improvement of safety and working conditions" partly supported in 20202022 - within the scope of research and development - by the National Centre for Research and Development.

The Central Institute for Labour Protection - National Research Institute is the Programme's main co-ordinator.

\section{REFERENCES}

[1] Balicki, W., Chachurski, R., Głowacki, P. and Szczeciński, S., 2014, "Aviation - Environmental threats," Journal of KONES Powertrain and Transport, 21(1), 7-14.

[2] Fleuti, E. and Polyméris J., 2004, Aircraft NOx-Emissions within the Operational LTO Cycle, Unique, Swiss International Air Lines.

[3] Głowacki, P. and Szczeciński, S., 2013, Transport lotniczy: Zagrożenia ekologiczne oraz sposoby ich ograniczania [Air Transport: Ecological Threats and Ways to Reduce Them], Scientific Publications of the Institute of Aviation, No. 35, p. 121, ISBN 978-83-63539-09-2.

[4] Głowacki, P. and Kawalec, M, 2015, "Aircraft emissions during various flight phases," Combustion Engines, 3(162), 229-240. PTNSS.

[5] Głowacki, P. and Kawalec, M., 2015, "Aircraft fuel consumption and emissions during cruise: Effect of the jet stream," Journal of KONES Powertrain and Transport, 22(2), 63-71. 
[6] ICAO, 2008, International Standards and Recommended Practices, Environmental Protection Annex 16, Volume II - Aircraft Engine Emissions ( $2^{\text {nd }} \mathrm{ed}$.)

[7] ICAO Engine Emissions Data Bank — current datasheets (version 27 of 22.08.2020).

[8] Kinsey John S., 2009, QEP. Characterization of Emissions from Commercial Aircraft Engines during the Aircraft Particle Emissions Experiment (APEX) 1 to 3, Office of Research and Development, U.S. Environmental Protection Agency, Washington DC.

[9] Merkisz, J., 1998, Ekologiczne problemy silników spalinowych [Ecological problems of internal combustion engines]. Vol. 1, Poznań, Wydawnictwo Politechniki Poznańskiej, ISBN 8371430701.

[10] Merkisz, J., 1999, Ekologiczne problemy silników spalinowych [Ecological problems of internal combustion engines]. Vol. 2, Poznań, Wydawnictwo Politechniki Poznańskiej, ISBN 8371430396.

[11] Orkisz, M., 2000, Konstrukcyjne metody obniżania emisji składników toksycznych emitowanych przez silniki turbinowe - Turbinowe silniki lotnicze w ujęciu problemowym [Design methods of reducing the emission of toxic components emitted by turbine engines - Turbine aircraft engines from the problem perspective], PNTTE, Lublin.

[12] Kalina, P., 2017, Dissertation, Influence of the combustion chamber geometry on the emission level of nitrogen oxides in compression-ignition engines, Warsaw: Institute of Aviation.

\section{SZACOWANIE EMISJI TOKSYCZNYCH SKŁADNIKÓW SPALIN WYTWARZANYCH PRZEZ SAMOLOTYW CYKLU STARTU I LAZDOWANIA W PRZESTRZENI PORTU LOTNICZEGO}

\section{Abstrakt}

W artykule przeanalizowano, w oparciu o dostępne informacje oraz ocenę autorów, wpływ gazów spalinowych z silników turbinowych na środowisko w przestrzeni wokół portu lotniczego podczas cyklu lądowania i startu (LTO) samolotów. Autorzy zwracają uwagę na fakt, że ilość spalin produkowanych przez silniki turbinowe jest na tyle znacząca, iż może niekorzystnie zmienić powietrze otaczające lotniska. Zwiększony poziom emisji tlenku węgla $(\mathrm{CO})$ i węglowodorów (HC) podczas rozruchu silnika i na biegu jałowym może więc stanowić zagrożenie dla zdrowia pracowników obsługi naziemnej. Wysoki poziom emisji tlenków azotu $\left(\mathrm{NO}_{\mathrm{x}}\right)$ podczas startu, wznoszenia, schodzenia i kołowania również nie jest obojętny dla środowiska wokół lotniska. W artykule najpierw przedstawiono szacunki emisji $\mathrm{CO}_{2}, \mathrm{HC}, \mathrm{CO}$ i $\mathrm{NO}_{\mathrm{x}} \mathrm{w}$ oparciu o normy ICAO oraz liczbę operacji pasażerskich na lotnisku średniej wielkości. Następnie obliczono szacunkowe emisje $\mathrm{CO}_{2}, \mathrm{HC}, \mathrm{CO}$ i $\mathrm{NO}_{\mathrm{x}}$ na podstawie danych pobranych z rejestratora lotu (FDR) podczas cyklu LTO różnych typów statków powietrznych na lotnisku. Te drugie obliczenia, oparte na rzeczywistych czasach manewrowych, wskazują na znacznie niższe szacunkowe emisje toksycznych gazów w obrębie portu lotniczego.

Słowa kluczowe: ekologia, lotniczy silnik turbinowy, spaliny silnika, toksyczne składniki spalin, tlenki azotu, tlenek węgla, węglowodory, dwutlenek węgla 